\title{
People's participation in joint forest management in higher hills of Himachal Pradesh
}

\author{
Chandresh Guleria ${ }^{1 *}$, Manoj Kumar Vaidya ${ }^{1}$, K. Kireeti ${ }^{1}$ and Chaman Negi ${ }^{4}$ \\ ${ }^{1}$ Department of Social Sciences, College of Forestry, Dr.Yaswant Singh Parmar University of Horticulture and \\ Forestry, Nauni, Solan (Himachal Pradesh), INDIA \\ ${ }^{2}$ Department of Agricultural Economics, College of Agriculture, Prof. Jayashankar Telangana State Agricultural \\ University, Hyderabad-500030 (Telengana), INDIA \\ *Corresponding author. guleriachandresh88@gmail.com
}

Received: May 17, 2016; Revised received: February 20, 2017; Accepted: May 16, 2017

\begin{abstract}
Joint Forest Management (JFM) is an effort which involved people to participate for the protection, conservation and rehabilitation of forests whilst safeguarding the rights of forest dwellers. Women and other marginalized sections of the community need to be empowered to ensure their participation in JFM (Aggarwal and Chauhan, 2015). Such programmes while ensuring the conservation of flora and fauna, also provided stability for the agriculture, horticulture, animal husbandry, and local cottage industries and thus, help in all round economic development (Bhatia, 2000). The present study analysed the people's participation in different stages of JFM programmes in the higher hills of Himachal Pradesh (Sundernagar and Kullu forest division). The results showed that people of age group 40-60 years participated most in the JFM programme. The participation of the general category people was found highest followed by scheduled caste, other backward class and scheduled tribe. The literacy rate of the respondents was found to be 98.51 percent while the literacy index was found to be 2.51 representing level of education in between middle class and higher secondary. In both the regions participation of people was found maximum during maintenance stage followed by planning stage and implementation stage. The overall participation index was found to be 61.91 per cent. The capacity building through training and awareness can help in safeguarding livelihood and conservation efforts of JFM.
\end{abstract}

Keywords: Implementation, JFM, Maintenance, Planning and PPI

\section{INTRODUCTION}

In Himachal Pradesh more than 66 percent of the area is under forest which in one way or the other is supporting the rural population of the state which constitutes around 89 per cent of the total population of the state. Also the large livestock population of around 48.50 lakh of the state depends on the forests for their survival. Rural people are dependent on forests for their day to day requirements of fuelwood, fodder, non -timber forest products and timber etc. to earn their livelihood. Besides they protect environment from pollution and maintain ecological balance. The forests contributed to the state net revenue of Rs 10654.48 Lakh in 2011-12 (Anonymous, 2013).

Emerged as an imperative intervention of national forest policy of 1988, focus shifted from commercial forestry towards participatory forestry for the conservation of resources as well as meeting livelihood needs of forest dependent households. In 1990 Ministry of Environment and Forests and the planning commission recommended involvement of village communities and voluntary agencies in regeneration of degraded forests. The policy visualised the state government and the local people, sharing the responsibility for managing the resource and the benefits accruing from a process of joint management of forests (Krishnan et. al., 2012). Proper forest management to regenerate degraded forests is not possible when people refuse to participate (Chopra et al., 1990; Palit, 1993; Poffenberger and McGean, 1998; Sarin, 1996).

JFM began in the state during 1993-94 when state government issued first notification for constitution of Village Forest Development committees (VFDCs). In 2001, Himachal Pradesh Participatory Forest Management Rules were issued for registration of Village Forest Development Societies (VFDSs) under the Societies Registration Act. Subsequently 2002-03 onwards Joint Forest Management Committees (JFMCs) were constituted and federated into Forest Development Authority (FDA) at the Forest Division level with support from National Afforestation Program (NAP). The programme aimed to provide people with access to and control over, resources and attempting to involve women to a large degree in resources management. Community organizations, called JFMC/ FPC, were formed at village levels. All villagers become members and each household has to be represented by a man and 


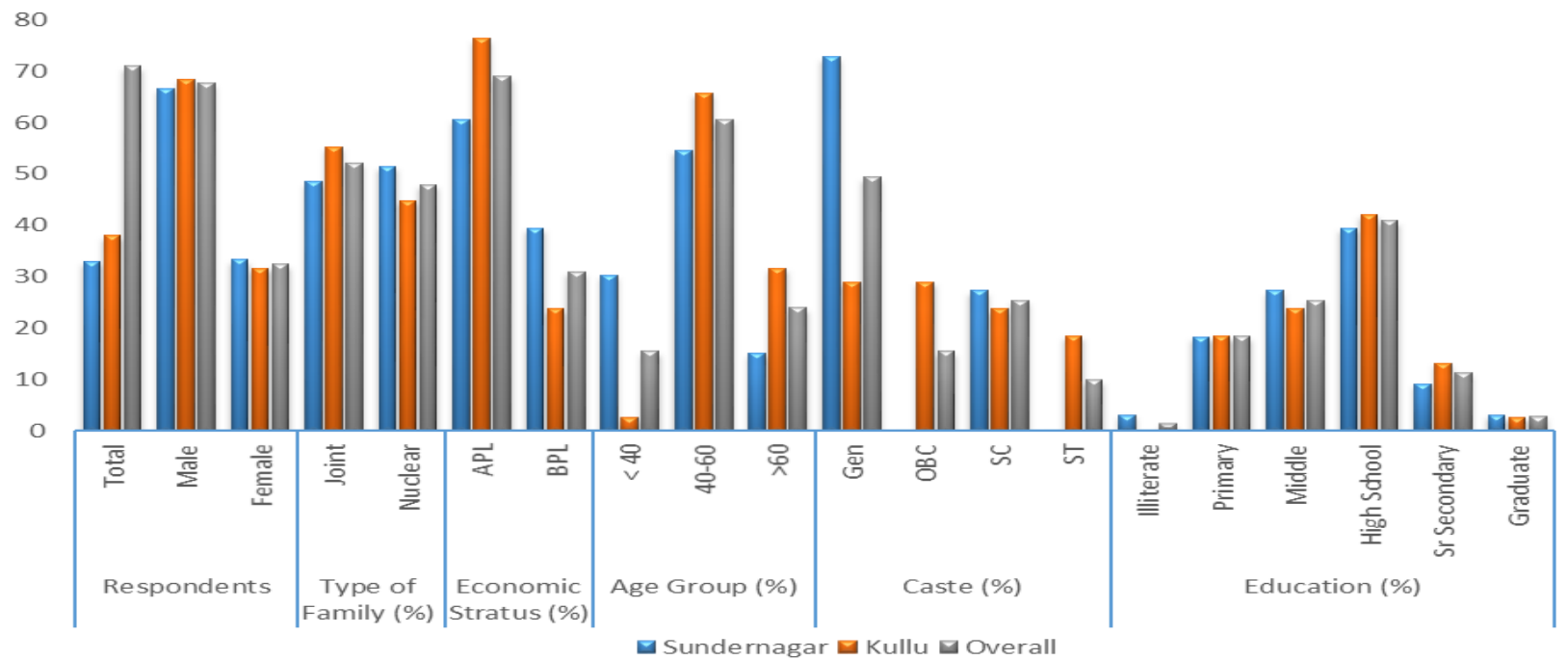

Fig. 1. Distribution of respondents on basis of socio-personal characters.

a woman. At present there are 1023 JFMCs in the state covering 2, 05,056 hectare area and involving 2,63,024 families (Anonymous, 2011).

Keeping in views the study was conducted with the objectives to assess the people's participation in joint forest management programmes in the upper hills of Himachal Pradesh being implemented through FDAs.

\section{MATERIALS AND METHODS}

A multistage random sampling design was used for the selection of the 71 respondents. In the first stage Kullu and Sundernagar forest circle was selected among different FDAs functioning in the upper hills of Himachal Pradesh for the present study. In the next stage of sampling, a 3 best working JFMCs among all, of the respective division were selected after consultation with the forest department to draw final respondents (Nathan, Haripur and Sajla from Kullu and Jhungi, Dhamasan and Badoo Kandi from Sundernagar). From the selected JFMCs a minimum of 10 respondents from each JFMC were selected randomly for survey. The primary data were collected through personal interview using a pre-tested questionnaire.

People participation Index (PPI): An index was developed to assess the extent of participation in a joint forest management programme operational in the concerned FDAs (Kumari et al., 2012; Sahibi, 2013). The people participation was also recorded in different stages of programme, viz., planning, implementation and maintenance. The people's participation index was worked out as under:

$$
\begin{aligned}
& P P I=\left\{\frac{\text { Mean Participation Score }(\mathrm{P})}{\text { Maximum Participation Score }}\right\} \times 100 \\
& P=\sum_{i=1}^{n} P_{i} / N
\end{aligned}
$$

Where,

$\mathrm{Pi}=$ mean people's participation

$\mathrm{N}=$ total number of people participating in programme

$$
P_{i}=\sum_{i=1}^{k}\left(P P_{j}+P I_{j}+P M_{j}\right)
$$

Where,

$\mathrm{PPj}=$ Total scores of people's participation in programme planning

$\mathrm{PIj}=$ Total scores of people's participation in programme implementation

$\mathrm{PMj}=$ Total scores of people's participation in programme maintenance

$\mathrm{K}=$ Total number of statements on which responses of respondents were recorded

Table 1. Economic characteristics of respondents in the study area.

\begin{tabular}{llll}
\hline Variables & Sundernagar & Kullu & Overall \\
\hline Literacy Rate & 96.97 & 100.00 & 98.59 \\
Literacy Index & 2.42 & 2.58 & 2.51 \\
\hline Land Holding (ha) & & & \\
\hline$<1$ & 61.65 & 54.74 & 57.95 \\
$1-2$ & 32.88 & 23.32 & 27.76 \\
$>2$ & 5.48 & 19.67 & 13.07 \\
\hline Occupation (\%) & & & 64.45 \\
\hline Agriculture & 49.32 & 77.59 & 30.97 \\
Government Job & 40.82 & 22.41 & 4.58 \\
Private Job & 9.86 & 0.00 & 3.07 \\
Livestock (Animal Cattle Unit) & 2.86 & 3.25 & \\
\hline
\end{tabular}




\section{RESULTS AND DISCUSSION}

The present investigation was focused exclusively on demographic and economic characteristics, participation with respect to age, caste and qualification, at different stages of FDA's implementation in the study area.

Socio-personal characteristics: Gender plays important role in the decision making and planning of any rural development programme. Women's role in the collection of fuelwood, fodder, non-timber forest produce from the forests cannot be neglected so there participation in any forest management programme is important (Bingeman, 2003; Britt-Kapoor, 1994; Kumari et. al., 2012; Sarkar and Das, 2002; Surya Kumari, 2001). It can be determined from figure 1 that the percentage of female respondents was 33.33 percent in Sundernagar, 31.58 percent in Kullu and 32.39 percent at an overall level. It was found that majority of respondents had joint family in Kullu region (55.26 \%) while nuclear family was found prominent in Sundernagar region $(48.48 \%)$. At an overall level, majority of respondents had joint family $(52.11 \%)$. Economic status had inverse relationship with the user of the forest viz, wealthier a person is less is his dependence on the forests. It was found in the study that majority of the population in study region was above poverty line which uses the forest resources. Age plays an important role in adjusting to any social and economic transformation. The person in older age group in gen- eral tends to be a less dynamic and novel. Therefore, age of respondents was considered to be an important factor determining the people's participation in JFM. Fig. 1 indicates the facts that 54.55 per cent in Sundernagar and 65.79 percent in Dehra people belonged to age group (40-60 years), respectively. Overall, 60.56 per cent of the respondents belonged to 40-60 years age group.

Caste is integral to the social structure of Indian villages. So, the distribution of respondents according to caste was studied and presented in Fig 1. The data indicated that majority of the respondents in Sundernagar were from general caste 72.73 per cent followed by scheduled caste respondents i.e. 27.27 per cent, while in Kullu majority population was of general category and other backward class respondents 28.95 per cent followed by scheduled caste and scheduled tribe respondents i.e. 23.68 and 18.42 percent respectively. Overall, majority population was of general category respondents.

Literacy: Education is important component for improvement of socio-economic conditions and providing healthy as well as clean environment for a quality living by widening the mental horizon of a person. Fig 1 explains that both the areas had good literacy rate, Kullu with 100 per cent literate respondents and Sundernagar having literacy rate of 96.97 per cent. At an overall level 98.59 per cent respondents were found literate. Despite of having high literacy rate the respondents had low quality of education. The literacy

Table 2. Distribution of respondent according to the responses about participation at programme planning stage.

\begin{tabular}{|c|c|c|c|}
\hline \multirow{2}{*}{ Statements } & \multicolumn{3}{|c|}{ (Per cent response) } \\
\hline & Sundernagar & Kullu & Overall \\
\hline Did you join the First PRA exercise? & 77.45 & 76.32 & 76.84 \\
\hline Did you have freedom to express your views in the general house? & 90.08 & 92.11 & 91.17 \\
\hline Were your views given due consideration in general house? & 74.97 & 73.68 & 74.28 \\
\hline Did you know about VFDCs at planning stage? & 64.78 & 68.42 & 66.73 \\
\hline Did you press for equal representation to all sections of the society in VFDC? & 55.73 & 57.89 & 56.89 \\
\hline Were you aware of the objectives of the project during planning stage? & 60.95 & 60.53 & 60.72 \\
\hline Were you involved in the formulation \& approval of micro plan? & 45.67 & 52.63 & 49.39 \\
\hline Were your suggestion incorporated in the micro plan? & 65.06 & 63.16 & 64.04 \\
\hline Did you involve in framing management and usufruct sharing rules? & 55.03 & 60.53 & 57.97 \\
\hline Did you make any suggestion about preferred tree species at this stage? & 50.37 & 39.47 & 44.54 \\
\hline Did you participate in baseline survey? & 40.31 & 44.74 & 42.68 \\
\hline Were you involved in the demarcation of JFM area? & 40.31 & 42.11 & 41.27 \\
\hline Planning Index & 60.06 & 60.96 & 60.54 \\
\hline \multirow{2}{*}{ Statements } & \multicolumn{3}{|c|}{ (Per cent response) } \\
\hline & Sundernagar & Kullu & Overall \\
\hline Did you attend the general house meeting regularly? & 69.70 & 76.32 & 73.24 \\
\hline Did you participate in plantation \& other programme activities? & 69.70 & 86.84 & 78.87 \\
\hline Did you receive any training during the course of the project? & 45.45 & 47.37 & 46.48 \\
\hline $\begin{array}{l}\text { Did you involve yourself in farm camp, field visits, field demonstration at organized } \\
\text { by VFDC? }\end{array}$ & 75.76 & 73.68 & 74.65 \\
\hline Did you get any employment in any of the project activities carried out by the project? & 69.70 & 52.63 & 60.56 \\
\hline $\begin{array}{l}\text { Did you help in collection of funds and donations for strengthening the income posi- } \\
\text { tion of VFDC? }\end{array}$ & 0.00 & 13.16 & 7.04 \\
\hline Did you provide any voluntary labour towards the project activities? & 57.58 & 63.16 & 60.56 \\
\hline Implementation Index & 55.41 & 59.02 & 57.34 \\
\hline
\end{tabular}


Table 4. Distribution of respondent according to the responses about participation at programme maintenance stage.

\begin{tabular}{|c|c|c|c|}
\hline \multirow{2}{*}{ Statements } & \multicolumn{3}{|c|}{ (Per cent response) } \\
\hline & Sundernagar & Kullu & Overall \\
\hline Do you involve in the protection of forest from grazing, illicit felling etc? & 72.73 & 86.84 & 80.28 \\
\hline Do you participate in extinguishing of forest fire/ maintenance of fire lines? & 69.70 & 89.47 & 80.28 \\
\hline Do you cooperate in reporting the poaching, stealing and illegal felling of forest? & 66.67 & 84.21 & 76.06 \\
\hline Do you normally comply with the set forest management rules? & 78.79 & 94.74 & 87.32 \\
\hline Do you help in preventing the free riding practices in the area? & 72.73 & 84.21 & 78.87 \\
\hline Are you involved in checking collected funds and accounts procedures? & 51.52 & 50.00 & 50.70 \\
\hline Do you raise the issue of transparency of VFDC accounts in the general house? & 48.48 & 55.26 & 52.11 \\
\hline $\begin{array}{l}\text { Are you willing to pay some amount for the forest products generated through project } \\
\text { interventions? }\end{array}$ & 48.48 & 50.00 & 49.30 \\
\hline Do you participate in suggesting the improvement in benefit sharing mechanism? & 48.48 & 57.89 & 53.52 \\
\hline Do you participate in creating awareness about creating social fencing? & 54.55 & 44.74 & 49.30 \\
\hline Are you disciplined enough to involve in social fencing? & 75.76 & 84.21 & 80.28 \\
\hline Do you involve in tending \& cultural operations? & 78.79 & 73.68 & 76.06 \\
\hline Maintenance Index & 63.89 & 71.27 & 67.84 \\
\hline
\end{tabular}

index of respondents in Kullu was found to be 2.58 while in Sundernagar it was 2.42, showing that the majority of respondents had education in between the middle class level and higher secondary level. The literacy index at an overall level was found to be 2.51 . Lamichhane (2004) in his study also revealed that more participation was in the age group of 29-45 years among women, who were mostly illiterate, and were more experienced in community forestry programme participation.

Economic characteristics: Economic characters such as respondent's occupation, land holding and literacy were studied and results have been presented in table 1. The occupation of a person indicated his economic status in the society. The study showed that agriculture was the main source of livelihood in both FDAs. The income, consumption, saving and investment is directly affected by land holding size of the households. The average size of total land holding of sampled respondents was examined and it was found that majority of the respondents in both the areas had marginal land holdings. It is evident from table 1 that 57.95 per cent of the respondents had marginal land holdings followed by respondents having small land holdings i.e. 27.76 per cent and 13.07 per cent with medium and large land holdings at an overall level. About 61.65 per cent respondents in Sundernagar and 54.74 per cent in Kullu area had land holding less than 1 ha. Livestock population also influences the dependence of rural people on forests so number of livestock with each household was also studied. It was found that respondents in Kullu region had more number of livestock (3.25 ACU) compared to Sundernagar area respondents (2.86 ACU). At an overall level the average number of animal cattle unit was found to be 3.07 per respondent.

Respondents participation in JFM programme at planning stage: The JFMC is basic unit of the FDAs, responsible for formulation and implementation of microplans with forest department as a partner. General house ensures both participation and accountabil- ity to provide checks and balances. The JFMC also maintain a bank account to ensure financial transparency. The responses of people in respect of planning stage have been presented in table 2 .

In both the divisions it was evident from table 2 that participation of people at planning stage was more than 60 per cent (60.06 and $60.96 \%$ in Sundernagar and Kullu divisions respectively). At an overall level the people participation at the planning stage was found to be 60.54 per cent.

Implementation stage: During implementation stage of FDA forest officers in association with locals conduct various activities. In this stage participation depends upon, involvement in general house meetings, plantation and other activities, cost sharing mechanism, trainings, farmer camps, collection of funds, provision of voluntary labour in various activities etc. Participation also depended upon timely availability of funds from forest department.

At this stage participation index value was observed to be 55.41 in Sundernagar while in Kullu it was only 59.02 per cent. But participation of people in collection of funds and training and awareness camps was observed very less in both the areas (table 3). At an overall level the people participation at the implementation stage was found to be 57.34 per cent.

Maintenance stage: Once the implementation stage is over the project officials hand over treated area to JFMC for maintenance and distribution of project benefits accruing from them. JFMC are responsible for fair distribution of project benefits, setting disputes between villages and for judicious use of existing rights. It becomes the moral duty of all the villagers to participate in the protection of treated area, report poaching and stealing cases to JFMCs, involve in social fencing, tending and cultural operation, preventing free riding practices, helping in cost and benefit sharing arrangements, disputes etc. Regarding this statements were recorded pertaining to participation in maintenance stage.

At maintenance stage participation of people was ob- 
Table 5. Participation Index at different stages of participation in FDA level.

\begin{tabular}{llll}
\hline \multirow{2}{*}{ Statements } & \multicolumn{3}{l}{ (Per cent response) } \\
\cline { 2 - 4 } & Sundernagar & Kullu & Overall \\
\hline Planning & 60.06 & 60.96 & 60.54 \\
Implementation & 55.41 & 59.02 & 57.34 \\
Maintenance & 63.89 & 71.27 & 67.84 \\
Participation Index & 59.79 & 63.75 & 61.91 \\
\hline
\end{tabular}

served more than 63 per cent in both the areas. In Kullu it was 71.27 per cent while in Sundernagar it was 63.89 percent. At an overall level the people participation at the maintenance stage was found to be 67.84 per cent (table 4).

Overall participation: Participation at the time of programme planning is much expected to take decisions as per the basic needs of the people of the local households. The participation in programme implementation and maintenance work is essential for project security and after care of project interventions, else the programme will not be successful.

Participation index was developed for each stage, in order to assess the participation at different stages of JFM programme. Table 5 shows that in Sundernagar the participation of people is maximum at maintenance stage i.e. 63.89 per cent followed by planning stage i.e. 60.06 per cent and implementation stage i.e. 55.41 per cent. Similarly in Kullu maximum participation was observed at maintenance stage i.e. 71.27 per cent followed by planning stage i.e. 60.96 per cent and implementation stage i.e. 59.02 per cent. Similar results were also found in the studies conducted by Kumari et al. (2012) and Sahibi (2013). The overall participation index was found to be 59.79 per cent in Sundernagar whereas in Kullu it was 63.75 percent. The higher participation in Kullu region can be generalized from the fact that higher proportion of population is related to agricultural activities and had higher number of cattle units compared to the Sundernagar region, where the large proportion of people was involved in government jobs compared to Kullu region. At an overall level people participation index was found to be 61.91 per cent. The participation index was found to be satisfactory as the people's involvement represented their awareness for the conservation of the forests resources.

\section{Conclusion}

From the study it can be concluded for any programme to be successful and sustainable it is obligatory that it takes care of the needs of the community. It should be inclusive in a way that the diverse sections of the society are fully involved. The results showed that people of age group 40-60 years participated most in the JFM programme. The participation of the general category people was found highest followed by scheduled caste, other backward class and scheduled tribe. The literacy rate of the respondents was found to be 98.51 percent while the literacy index was found to be 2.51 representing level of education in between middle class and higher secondary class level. In both the regions participation of people was found maximum during maintenance stage followed by planning stage and implementation stage. The overall participation index was found to be 61.91 per cent which was satisfactory as per the mandates of the project. The capacity building training and awareness camps can help both the forest dependents as well as the forest department by providing a source of employment and simultaneously conserving the forest resources, in eventually increasing the level of participation in such activities.

\section{ACKNOWLEDGEMENTS}

The author is highly thankful to members of VFDC's, officials of National Afforestation and EcoDevelopment Board (NAEB) and forest department officials of the study area for providing necessary information $\&$ nice stay during the research work.

\section{REFERENCES}

Aggarwal, A. and Chauhan, S. (2015). Green growth and forestry in Himachal Pradesh. Reviewer: J. V. Sharma. The Energy and Resources Institute: New Delhi: 16p

Anonymous. (2011). National Workshop on JFM Proceedings, FRI Dehradun. http://www.frienvis.nic.in/ Database/JFM-Committees-and-Forest-Area-UnderJFM 1994.aspx

Anonymous. (2013). Himachal Forest Statistics. Forest Department Himachal Pradesh

Bhatia, A. (2000). Participatory forest management: implications for policy and human resources development in the Hindu Kush-Himalayas. Volume 4-India. International centre for Integrated Mountain Development, Kathmandu, Nepal, pp. 25-121

Bingeman, K. (2003). Women participation in forest management decisions in the upper Kullu valley, Himachal Pradesh, India, Himalayan Research Bulletin, XXI 2: 53-61

Britt-Kapoor, C. (1994). A tale of two committees: villager perspectives on local institutions, Forest Management and Resource use in two central Himalayan Indian villages. ODI Rural Development Forestry Network paper $17 \mathrm{a}$, London

Chopra, K., Kadekodi, G.K. and Murty, M.N. (1990). Participatory Development, People and Common Property Resources. New Delhi: Sage publications. 163p

Krishnan, P., Ramakrishnan, R., Saigal, S., Nagar, S., Faizi, S., Panwar, H.S., Singh, S. and Ved, N. (2012). Conservation Across Landscapes: India's Approaches to Biodiversity Governance. UNDP, New Delhi, India. 186p

Kumari, A., Kaushal, P., Dubey, J.K. and Sharma, R. (2012). Women participation in forest development agencies (FDA's): a study of Himachal Pradesh and Punjab. Asian Academic Research Journal and Multidisciplinary, 1(1): 1-11

Lamichhane, D. (2004). Decision Making Role of Women in Community Forestry- a Case Study from Syangja District. Dissertation, Tribhuvan University, Nepal

Palit, S. (1993). The Future of Indian Forest Management: 
into the Twenty-first Century. New Delhi: Ford Foundation. Joint Forest Management Working Paper 15

Poffenberger, M. and McGean, B. (1998). Village Voices, Forest Choices, Joint Forest Management in India. Delhi: Oxford University press. 386p

Sarin, M. (1996). Joint forest management: the Haryana experience environment and development series. Ahmedabad, India: Centre for Environment Education, Nehru Foundation for Development, Thaltej Takra

Sahibi, G. R. (2013). Analysing participatory forest manage- ment approach in rural areas of Sirmour, Himachal Pradesh. PhD Thesis- Himalayan Forest Research Institute, Indian Council of Forestry Research \& Education, FRI (Deemed) University Centre Shimla. 291p

Sarkar, D. and Das, H. (2002). Women's participation in forestry, some theoretical issues. Economic and Political Weekly, 37(43): 4407-4412

Surya Kumari, D. (2001). Involvement of women in joint forest management (JFM) in Andhra Pradesh stategrass roots concerns. Energy News, 4(2):13-14 